\title{
Frequency of Red Cell Alloimmunization Among Patients with Transfusion Dependent Beta Thalassemia in Pakistan
}

\author{
Muhammad USMAN ${ }^{1}$, Saira MOIN ${ }^{1}$, Moinuddin Moinuddun ${ }^{1}$, Saeed AHMAD ${ }^{2}$, Rehana PERVEEN $^{3}$, \\ Muhammad A. AZMI', Sadia USMAN ${ }^{1}$ \\ ${ }^{1}$ Baqai Medical University, Department of Hematology \\ ${ }^{2}$ Husaini Institute of Hematology and Oncology Trust \\ ${ }^{3}$ Baqai Medical University, Department of Pharmacology \\ ${ }^{4}$ Baqai Medical University, Department of Physiology, Karachi, PAKISTAN
}

\begin{abstract}
Development of red cell alloantibodies complicates transfusion therapy in multi transfused beta thalassemia patients. This study was designed to determine the frequency of red cell alloantibodies in patients with transfusion dependent beta thalassemia in Pakistani population. This is a cross-sectional descriptive study conducted at Baqai Institute of Hematology, Baqai Medical University and Husaini Institute of Hematology and oncology Karachi. A total of 800 transfusion dependent patients with beta thalassemia from different thalassemia centers in Karachi were included in this study to determine the frequency of red cell alloantibodies. Of 800 patients with transfusion dependent beta thalassemia, 30 (3.75\%) patients developed red cell alloantibodies. These red cell alloantibodies were against Rh, Lewis, Duffy and Kell blood group systems. Results of this study indicate low frequency of red cell alloimmunization in Pakistani thalassemic population. This implies that there is homogeneity of red cell antigens in blood donors and recipients in Pakistani population. Red cell alloantibody formation was not influenced by age at the first transfusion, number of blood transfusions or splenectomy. Routine pre-transfusion phenotyping of blood, other than $\mathrm{ABO}$ and $\mathrm{Rh}$ "D" antigens is not recommended because of low rate of red cell alloimmunization and high cost of such testing.
\end{abstract}

Keywords: Alloimmunization, Transfusion dependent, Beta thalassemia, Pakistani population

\section{ÖZET}

\section{Pakistanda Transfüzyona Bağımlı Beta Talassemi Olgularında Eritrosit Alloimmünizasyon Sıklığı}

Çoklu transfüzyon yapılan beta talassemi hastalarında eritrosit alloantikorlarının gelişmesi transfüzyon komplikasyonu olarak karşımıza çıkar. Baqai ve Husaini Enstitülerinde yapılan bu kesitsel çalışma Pakistan toplumunda transfüzyon bağımlı beta talassemi olgularında eritrosit alloantikor gelişim sıklığını belirlemek üzere yapılmıştır. Karachi'deki farklı merkezlerden toplam 800 hastada eritrosit alloantikorlarının sıklı̆̆ına bakılmıștır. Bu 800 hastanın 30'unda (\%3.75) eritrosit alloantikorları saptanmıştır. Bunların Rh, Lewis, Duffy ve Kell kan grubu antikorlarına karşı oldukları anlaşılmıştır. Pakistandaki talassemi hastalarında alloimmünizasyon oranının düşük olduğu dikkati çekmiştir. Bu, kan verenler ve alanlardaki eritrosit antijenlerinin homojen olduğunu göstermektedir. Ayrıca çalışmamızda, ilk transfüzyondaki hasta yaşı, transfüzyon sayısı ve splenektominin alloantikor oluşumunu etkilemediği gösterilmiştir. Düşük eritrosit alloimmünizasyonu ve testlerin pahalı olması nedeniyle transfüzyon öncesi $A B O$ ve Rh "D" antijenlerinden başka kan fenotiplemesini önermemekteyiz.

Anahtar Kelimeler: Alloimmünizasyon, Transfüzyona bağımlı, Beta talassemi, Pakistan toplumu 


\section{INTRODUCTION}

Thalassemia is the most common genetic disorder across the globe. ${ }^{1,2}$ The term thalassemia comes from a Greek word "thalas" which means the sea, and "emia" that stands for blood. ${ }^{3,4}$ The composite word came into use because this type of anemia was originally described in countries bordering the Mediterranean Sea. Thalassemia was not recognized as a clinical entity until 1925, when Cooley and Lee, described a syndrome occurring early in life that was associated with splenomegaly and bony deformities. ${ }^{4,5}$

Beta thalassemia is the most common genetic disorder in Pakistan. ${ }^{6}$ The recommended treatment for beta thalassemia major involves regular blood transfusions, usually administered every 2 to 5 weeks. ${ }^{7}$ One of the hazards of regular blood transfusion is the development of alloantibodies. Alloimmunization to erythrocyte antigens is one of the major complications in beta thalassemia, particularly in those patients who are regularly transfused. Exposure to foreign blood group antigens during multiple blood transfusions increases the likelihood of alloimmunization in susceptible recipients. ${ }^{8}$ Development of one or more immune blood group antibodies complicates the selection of compatible blood for subsequent transfusion. It may also lead to diminished survival of the transfused red blood cells and hemolytic transfusion reactions should the antibody screening and compatibility testing be less than adequately perfect..$^{910}$

Factors that predispose to alloimmunization are complex and involve at least 3 main contributing elements, antigenic difference between the donor's and the recipient's red cells, recipient's immune status and the immunomodulatory effect of the allogenic blood transfusions on the recipient's immune system..$^{9,11,12}$

Alloimmunization to minor blood group antigens is reported in about 5-30\% of patients in different population. Because of the high frequency in different populations and its life threatening consequences, a study was designed to determine the frequency of red cell alloimmunization in the Pakistani population.

\section{MATERIAL AND METHODS}

This multi-centre study was conducted at Baqai institute of hematology, Baqai Medical University, Husaini Institute of Hematology and Oncology Trust, Karachi. A total of 800 transfusion dependent thalassemic patients were included in this study.

Using standard venesection technique serum samples were collected from 800 multi-transfused beta thalassemic major patients. All samples were screened for alloantibodies by using panel of cells of antibody screening (DiaMed-ID Diluent 2) and DiaMed ID Gel system.

Antibody identification was carried out on samples that tested positive in antibody screening procedure. For the identification of antibodies, panel cells of antibody identification (DiaMed-Dia Panel) and DiaMed Gel cards were used. Results were analyzed by SPSS statistical software version 17.0.

\section{RESULTS}

A total of 800 transfusion dependent beta thalassemia patients (with repeated incompatible cross match) were included in this study, 350 patients were male and 450 patients were female. Mean age of patients who developed red cell alloantibody was 11.5 years. Patients who did not develop red cell alloantibody aged 10-23 years with a mean age of 11.1 years. Red cell alloimmunization was found in $30(3.75 \%)$ patients. These alloantibodies were against Rh, Lewis, Duffy and Kell blood groups systems. Alloantibodies that were detected during this study are listed in Table 1.

Results of this study also showed that development of alloantibodies was not influenced by number of blood transfusions; data is listed in Table 2 .

\section{DISCUSSION}

Beta thalassemia is the most common monogenic disorder in Pakistan. The recommended treatment for beta thalassemia major includes regular blood transfusions, usually administered every 2 to 5 weeks. One of the hazards of regular blood transfusion is the development of alloantibodies. This study was conducted to detect frequency of red cell alloimmunization in transfusion dependent thalassemia 
Table 1. Frequency of alloantibodies in transfusion dependent beta thalassemia

\begin{tabular}{|lll|}
\hline Alloantibody & Frequency in total samples $(800)$ & Frequency in alloantibodies positve samples (30) \\
\hline anti-D & $08(1 \%)$ & $08(26.6 \%)$ \\
anti--E & $07(0.87 \%)$ & $07(23.3 \%)$ \\
anti-C & $06(0.75 \%)$ & $06(20 \%)$ \\
anti-C & $05(0.62 \%)$ & $05(16.7 \%)$ \\
anti-K & $02(0.25 \%)$ & $02(6.66 \%)$ \\
anti-Leb & $01(0.125)$ & $01(3.3 \%)$ \\
anti-Fyb & $01(0.125)$ & $01(3.3 \%)$ \\
\hline
\end{tabular}

patients. Out of 800 multi transfused beta thalassemic patients $30(3.75 \%)$ patients developed red cell alloantibodies.

Frequency of red cell alloimmunization was $3.75 \%$ in this study. Eight (26.6\%) patients developed anti $\mathrm{D}$, seven $(23.3 \%)$ patients developed anti E, six $(20 \%)$ patients developed anti C, five $(16.7 \%)$ patients developed anti C, two (6.6\%) patients developed anti $\mathrm{K}$, one (3.3\%) patient each developed anti Leb and anti Fyb. These alloantibodies were mainly against $\mathrm{Rh}$ blood group system.

The observed frequency of red cell alloimmunization is relatively low in our study compared to the reported incidence in the literature. Red cell alloimmunization in multi transfused beta thalassemia major patients from different population was reported with variable frequencies such as $30 \%$ in Kuwa$\mathrm{iti}^{13}, 22.6 \%$ in $\mathrm{Greece}^{8}, 22 \%$ in $\mathrm{Arabs}^{14}, 9 \%$ in Net- herlands population ${ }^{15}, 9 \%$ in Malaysian ${ }^{7}$ and $5.2 \%$ in Italian population. ${ }^{9}$ Overall the frequency ranges between $5-30 \%$.

Low frequency of red cell alloimmunization in this study suggests that there is homogeneity of red cell antigens in blood donors and recipients in Pakistani population.

Red cell alloimmunization is an important development in transfusion dependent beta thalassemic patients. The important factor that contributes towards red cell alloimmunization is the antigen dissimilarity between blood donors and recipients. This study also revealed that red cell alloantibody formation was not influenced by age at first transfusion, number of blood transfusions (Table 2) and splenectomy. Several other factors might have contributed to the low incidence of alloimmunization in this study, such as the recipient's immune sta-

Table 2. Distribution of patients with alloantibodies according to number of transfusion

\begin{tabular}{|llll|}
\hline Sample No & No. of Patients & No. of transfusions & No. of patients with alloantibodies \\
\hline 01 & 80 & $5-20$ & $06(7.5 \%)$ \\
02 & 110 & $21-35$ & $08(7.3 \%)$ \\
03 & 130 & $36-50$ & $06(4.6 \%)$ \\
04 & 130 & $51-65$ & $02(1.5 \%)$ \\
05 & 100 & $66-80$ & $03(3.0 \%)$ \\
06 & 130 & $81-95$ & $02(1.5 \%)$ \\
07 & 120 & $>100$ & $03(2.5 \%)$ \\
Total & 800 & ---- & $30(3.75 \%)$ \\
\hline
\end{tabular}


tus and immunomodulatory effects of the allogenic blood transfusion on the recipient's immune system.

To prevent alloimmunization against red cell antigens the recommendation is to provide antigenmatched red cells to all transfusion dependent thalassemic patients. It is true that providing antigenmatched blood will effectively prevent alloimmunization; however, the cost effectiveness to establish such programs for chronically transfused patients is debatable. It is also difficult to establish and maintain a personalized donor pool for each patient. In the existing setup it is felt that there is no pressing need for routine pre-transfusion matching of blood other than $\mathrm{ABO}$ and $\mathrm{Rh}$ " $\mathrm{D}$ " antigens. Low rate of red cell alloimmunization and high cost associated with such testing also testify this contention.

Conclusion: Red cell alloimmunization is an important development in patients with transfusion dependent beta thalassemia. Results of this study revealed low frequency of red cell alloimmunization in Pakistani thalassemic population. Low frequency of red cell alloimmunization probably reflects homogeneity of red cell antigens in blood donors and recipients in Pakistani population. Red cell alloantibody formation was not influenced by age at first transfusion, number of blood transfusions and splenectomy. Routine pre-transfusion matching of blood, other than $\mathrm{ABO}$ and $\mathrm{Rh}$ " $\mathrm{D}$ " antigens is not recommended because of low rate of red cell alloimmunization and high costs associated with such testing.

\section{REFERENCES}

1. Quek L, Thein SL. Molecular therapies in beta thalassemia. Br J Haematol 136: 353-365, 2007.

2. Pan HF, Long GF, Li Q, et al. Current status of thalassemia in minority population in Guangxi, China. Clin Genet 71: 419-426, 2007.

3. Bun HF, Forget BG. Hemoglobin: Molecular genetics and clinical aspects. WB Saunders, Philadelphia, 1986.

4. Cooley TB, Lee P. A series of cases of splenomegaly in children with anemia and peculiar changes. Trans Am Pediatr Soc 37: 29, 1925.

5. Weatherall DJ, Clegg JB. Historical perspective: The many and diverse routes to our current understanding of the thalassemia syndrome. In: The thalassemia syndrome. 4th ed. Oxford, Blackwell Science, 2001: 3-64.
6. Baig SM, Azhar A, Hassan H, et al. Prenatal diagnosis of beta-thalassemia in Southern Punjab, Pakistan. Prenat Diagn 26: 903-905, 2006.

7. Noor Haslina MN, Ariffin N, Illuni Hayati I, Rosline $\mathrm{H}$. Red cell immunization in multiply transfused Malay thalassemic patients. Southeast Asian J Trop Med Public Health 5: 1015-1020, 2006.

8. Spanos TH, Kargeorga M, Ladis $\mathrm{V}$, et al. Red cell alloantibodies in patients with thalassemia. Vox Sang 58: 50-55, 1990.

9. Sirchia G, Zanella A, Parravivini A, et al. Red cell alloantibodies in thalassemia major. Transfusion 25:110112,1985

10. Schonewille $\mathrm{H}$, de Vries RR, Brand A. Alloimmune response after additional red blood cell antigen challenge in immunized hematooncology patients. Transfusion 49: 453-457, 2009.

11. Tormey CA, Fisk J, Stack G. Red blood cell alloantibody frequency, specificity and properties in a population of male military veterans. Transfusion 48: 20692076, 2008.

12. Shamsian BS, Arzanian MT, Shamshiri AR, et al. Frequency of red cell alloimmunization in patients with beta major thalassemia in an Iranian referral hospital. Iran J Pediater 18: 149-153, 2008.

13. Ameen R, Al-Shemmari S, Al-Humood S, et al. RBC alloimmunization and autoimmunization among transfusion-dependent Arab thalassemia patients. Transfusion 43: 1604-1610, 2003.

14. Gader AG, Al Ghumlas AK, Al-Momen AK. Transfusion medicine in developing country - alloantibodies to red blood cell in multi-transfused patients in Saudi Arabia. Transfus Apher Sci 39:199-204, 2008.

15. Schonewille H, Haak HL, van Zijli AM. Alloimmunization after blood transfusion in patients with hematologic and oncologic disease. Transfusion 39: 763-771, 1999.

\section{Correspondence}

Muhammad USMAN

Baqai Medical University

Institute of Hematology

Karachi / PAKISTAN

Tel: 92-21-2224789

92-322-3561923

e-mail: staytune1@hotmail.com 